\title{
PENGARUH HARGA JUAL DAN VOLUME PENJUALAN TERHADAP PENDAPATAN UD. BROILER PUTRA DI DUSUN BATUMULAPAN KABUPATEN KLUNGKUNG PADA TAHUN 2015-2017
}

\author{
Ni Wayan Ari Santi ${ }^{1}$, Iyus Akhmad Haris², I Nyoman Sujana ${ }^{3}$ \\ Program Studi Pendidikan Ekonomi \\ Universitas Pendidikan Ganesha \\ Singaraja, Indonesia \\ email: wayanarisanti08@gmail.com¹, iyusharis55@gmail.com², \\ nyoman.suiana@undiksha.ac.id ${ }^{3}$
}

\begin{abstract}
Abstrak
Penelitian ini bertujuan untuk mengetahui pengaruh harga jual dan volume penjualan terhadap pendapatan UD. Broiler Putra baik secara parsial maupun simultan. Jenis penelitian ini merupakan jenis penelitian kausal. Data dikumpulkan dengan metode dokumentasi. Metode analisis data yang digunakan adalah analisis regresi linear berganda. Hasil penelitian menunjukkan bahwa ada pengaruh positif dan signifikan secara parsial harga jual terhadap pendapatan UD. Broiler Putra, yang ditunjukkan dengan koefisiaen regresi sebesar 6,104, dan nilai signifikan uji t sebesar 0,000 yang berarti lebih kecil dari 0,05 atau $\alpha=5 \%$, ada pengaruh positif dan signifikan secara parsial volume penjualan terhadap pendapatan UD. Broiler Putra, yang ditunjukkan dengan koefisiaen regresi sebesar 24,035, dan nilai signifikan uji t sebesar 0,000 yang berarti lebih kecil dari 0,05 atau $\alpha=5 \%$, ada pengaruh positif dan signifikan secara simultan harga jual dan volume penjualan terhadap pendapatan UD. Broiler Putra, yang ditunjukkan dengan koefisiaen regresi sebesar 766,870. Dan nilai signifikan uji F sebesar 0,000 yang berarti lebih kecil dari 0,05 atau $\alpha=5 \%$.
\end{abstract}

Kata-kata kunci: harga jual, pendapatan, volume penjualan.

\begin{abstract}
Abstrak
This study aims to know the effect of selling prices and sales volume on UD. Broiler Putra both partially and simultaneously. This type of research is a type of causal research. Data collected by documentation method. The data analysis method used is multiple linear regression analysis. The results showed that there was a positive and significant effect partially selling price on the income UD. Broiler Putra which is indicated by regression coefficient of 6.104 , and a significant value of $t$ test is 0.000 which means less than 0.05 or $\alpha=5 \%$, there is a positive and significant influence partially on the sales volume on revenue of UD. Putra Broiler, which is indicated by regression coefficient of 24,035 , and significant value of $t$ test is 0,000 which means smaller than 0.05 or $\alpha=5 \%$, there is a positive and significant effect simultaneously selling price and sales volume on revenue UD. Broiler Putra, which is indicated by regression coefficient of 766,870 . And the significant value of the $F$ test is 0,000 which means it is smaller than 0.05 or $\alpha=5 \%$.
\end{abstract}

\section{PENDAHULUAN}

Keywords: selling price, income, sales volume.

Perusahaan didirikan untuk proses produksi yang nantinya akan dikonsumsi oleh konsumen. Ciri- ciri badan perusahaan yaitu mencari keuntungan, memenuhi kebutuhan masyarakat, menggunakan modal dan tenaga kerja, dan dipimpin oleh seorang pemimpin. Ada banyak anggapan mengenai dibangunnya perusahaan, seperti ada yang beranggapan bahwa dibangunnya perusahaan untuk meningkatkan taraf hidup pemilik perusahaan, ada juga yang beranggapan bahwa perusahaan bertujuan untuk mencapai pendapatan yang maksimal. Setiap perusahaan memiliki sasaran yang berbeda, perusahaan 
menginginkan pendapatan atau keuntungan yang maksimal dari perusahaan yang dikelolanya. Karena, tujuan utama perusahaan adalah untuk memperoleh laba yang maksimal. Untuk mencapai tujuan tersebut terdapat beberapa unsur usaha yang harus dipenuhi, diantaranya adalah modal, tenaga kerja, dan keahlian dalam mengelola usaha tersebut. Usaha apapun dihadapkan oleh masalah ketidakpastian, karena setiap perusahaan tidak bisa memastikan apa yang akan tertjadi pada masa yang akan datang. Untuk mengatasi hal tersebut, perusahaan perlu membuat perencanaan untuk mengatasinya.

Agar memudahkan perusahaaan untuk mengetahui apakah perusahaan mendapatkan atau mengalami kerugian perusahaan harus menggunakan laporan laba rugi. Menurut Hery (2009) bahwa laporan laba rugi adalah laporan yang menyajikan ukuran keberhasilan operasi perusahaan selama periode waktu tertentu. Tujuan mendirikan sebuah perusahaan tidak lain untuk memperoleh keuntungan yang dapat dipergunakan untuk kelangsungan hidup. Pada hakekatnya setiap perusahaan yang didirikan mempunyai tujuan untuk mengembangkan dan memajukan usahanya. Perkembangan suatu usaha pada dasarnya menginginkan tercapainya suatu tujuan yaitu memperoleh laba atau pendapatan yang maksimal. Sedangkan usaha untuk mencapai pendapatan yang maksimal tidak bisa dipisahkan dari masalah penjualan, peningkatan penjualan, dan penentuan harga jual. Menurut Dyekman (2002:234): pendapatan merupakan arus masuk atau peningkatan lainnya atas aktiva sebuah penyelesaian kewajiban selama satu periode dari pengiriman atau produksi, penyediaan jasa, atau aktivitas lain yang merupakan operasi utama atau sentral entitas yang sedang berlangsung. Pendapatan merupakan penghasilan yang tiimbul dari usaha perusahaan yang biasa disebut penjualan. Pendapatan yang diperoleh usaha dagang nantinya akan digunakan untuk memperluas usahanya. Setiap usaha pasti mengharapkan hal-hal positif demi kelangsungan usahanya dan agar usaha yang dibangun tetap eksis dalam dunia perbisnisan. Untuk mendapatkan pendapatan yang maksimal setiap usaha harus mempertimbangkan harga jual dari produk yang dihasilkan oleh perusahaan tersebut. Harga jual harus sesuai dengan biaya-biaya yang dikeluarkan selama proses produksi berlangsung. Harga jual yang ditetapkan bertujuan untuk menutupi biaya-biaya yang dikeluarkan selama proses produksi.

Dalam perusahaan dikenal dengan adanya pendapatan, yaitu kemampuan setiap perusahaan dalam memenuhi kebutuhan materinya dalam kurun waktu tertentu. Pendapatan diukur dengan jumlah rupiah yang diterima dari pembeli atau konsumen. Menurut Adji (2004), bahwa pendapatan adalah uang yang diterima oleh seseorang dan perusahaan dalam bentuk gaji, upah, sewa, bunga, dan laba, termasuk juga beragam tunjangan seperti kesehatan dan pensiun. Dengan demikian pendapatan akan diakui saat terjadinya perubahan bentuk barang atau jasa menjadi bentuk kas atau alat pembayaran yang sah lainnya. Adapun faktor-faktor yang mempengaruhi pendapatan menurut Mulyadi (2008:513) yaitu biaya, harga jual, dan volume penjualan. Biaya yang timbul dari perolehan atau mengolah suatu produk/jasa akan mempengaruhi harga jual produk yang bersangkutan. Harga jual produk/jasa akan mempengaruhi besarnya volume penjualan produk/jasa yang bersangkutan. Besarnya volume penjualan berpengaruh terhadap volume produksi, akan mempengaruhi besar kecilnya biaya produksi. Untuk mendapatkan pendapatan yang maksimal setiap usaha harus mempertimbangkan harga jual dari produk yang dihasilkan oleh perusahaan tersebut. Harga jual harus sesuai dengan biaya-biaya yang dikeluarkan selama proses produksi berlangsung.

Pendapatan peternak juga sangat dipengaruhi oleh harga jual ayam di pasaran, penetapan harga jual yang tepat adalah salah satu faktor yang sangat penting bagi setiap perusahaan dalam menjalankan usahanya yang bertujuan untuk memperoleh laba. Perusahaan akan selalu menetapkan harga pokok dengan harapan produk yang dihasilkan oleh 
perusahaan tersebut laku terjual dan mampu mendapatkan laba yang maksimal. Penentuan harga jual sangat penting dilakukan oleh perusahaan. Harga jual yang ditetentukan juga harus bisa bersaing di pasaran. Harga jual akan mempengaruhi konsumen dalam memilih atau membeli produk, semakin tinggi harga jual apabila sesuai dengan manfaat yang diterima oleh konsumen, mereka akan tertarik untuk mengkonsumsi produk yang ditawarkan tersebut. Menurut Kotler (dalam Sunyoto, 2012) bahwa harga adalah sejumlah uang yang dibebankan pada suatu produk tertentu. Harga jual akan mempengaruhi tingkat pendapatan suatu perusahaan dan juga dapat meningkatkan taraf hidup usaha yang telah dijalankan tersebut.

Dalam operasi perusahaan harus memperhitungkan harga jual produk tentunya didasari dengan perhitungan harga pokok produksi. Penentuan harga yang relative tinggi untuk memperoleh laba yang tinggi pula (Rangkuti, 2001:121). Dapat disimpulkan bahwa harga jual produk yang dihasilkan oleh perusahaan dapat mempengaruhi pendapatan yang akan diperoleh perusahaan jalam jangka waktu tertentu. Menurut Supriyono (2009:32), bahwa harga jual merupakan jumlah moneter yang dibebankan oleh suatu unit usaha kepada pembeli atau pelanggan atas barang atau jasa yang dijual atau diserahkan. Adapun faktor-faktor yang mempengaruhi penjualan menurut Kotler (2005) adalah yaitu harga jual adalah jumlah moneter yang dibebankan kepada suatu unit usaha kepada pembeli atau pelanggan atas barang atau jasa yang dijual atau diserahkan. Pada prinsipnya harga jual harus dapat menutup biaya penuh ditambah dengan laba yang wajar. Harga jual sama dengan biaya produksi ditambah mark-up. Produk adalah segala sesuatu yang dapat ditawarkan ke suatu pasar untuk memenuhi keinginan atau kebutuhan dan sebagai suatu sifat yang kompleks baik dapat diraba, termasuk bungkusan, warna, harga, persentase perusahaan dan pengecer, pelayanan perusahaan dan pengecer yang diterima oleh pembeli untuk memuaskan kebutuhan dan keinginannya. Biaya promosi adalah pengorbanan ekonomis yang dikeluarkan perusahaan untuk melakukan promosinya. Dengan demikian biaya promosi adalah biaya pemasaran atau biaya penjualan yang meliputi seluruh biaya yang diperoleh untuk menjamin pelayanan konsumen dan penyampaian produk jadi atau jasa ke tangan konsumen. Mutu atau kualitas merupakan suatu kondisi dinamis yang berhubungan dengan produk, jasa manusia, proses, dan lingkungan yang memenuhi atau melebihi harapan. Kualitas merupakan suatu tingkat yang dapat diprediksi dari keseragaman dan ketergantungan pada biaya yang rendah dan sesuai dengan pasar. Saluran distribusi suatu perusahaan dapat menentukan penyaluran produknya melalui pedagang menengah atau subdistributor dan meneruskannya ke pengecer yang menjual produk itu kepada pemakai atau konsumen. Dalam menentukan harga jual ada beberapa faktor yang harus dipertimbangkan. Menurut Kotler dan Amstrong (dalam Tjiptono, 2005) bahwa secara umum ada dua faktor yang harus dipertimbangkan, yaitu faktor internal dan faktor lingkungan eksternal. Faktor internal perusahaan meliputi tujuan pemasaran perusahaan, strategi bauran pemasaran, biaya, dan organisasi. Sedangkan faktor lingkungan eksternal meliputi sifat pasar dan permintaan, persaingan, dan unsurunsur lingkungan eksternal lainnya.

Selain harga jual yang menentukan pendapatan yang akan diperoleh, ada faktor lain yang mempengaruhi pendapatan yaitu volume penjualan. Penjualan juga akan mempengaruhi besarnya pendapatan yang akan diperoleh oleh perusahaan. Dalam memasuki pasar untuk meningkatkan penjualan, perusahaan harus melakukan proses pemasaran terlebih dahulu. Menurut Jakfar dan Kasmir (2012:47), pemasaran dapat diartikan sebagai upaya untuk menciptakan dan menjual produk kepada berbagai pihak dengan maksud tertentu. Semakin banyak barang atau produk yang berhasil dijual semakin besar pendapatan suatu perusahaan. Dan juga sebaliknya apabila kecil tingkat penjualan suatu produk maka pendapatan yang diperoleh oleh 
perusahaan juga akan kecil. Menurut Zulkarnain (2012:10) bahwa penjualan merupakan tujuan dari pemasaran artinya perusahaan melalui departemen/bagian pemasaran termasuk tenaga penjualan (sales force) nya akan berupaya melakukan kegiatan penjualan untuk menghabiskan produk yang dihasilkan. Dalam kegiatan pemasaran, kenaikan volume penjualan merupakan merupakan efisiensi, meskipun tidak setiap kenaikan volume penjualan diikuti dengan kenaikan laba. Untuk mencapai penjualan yang maksimal, perusahaan harus menargetkan banyaknya penjualan produk dalam jangka waktu tertentu.

$$
\text { Volume penjualan yang }
$$

menguntungkan harus menjadi tujuan perusahaan, dan bukannya volume untuk kepentingan volume itu sendiri (Swastha, 2007:17). Dalam proses penjualan, penjual atau penyedia barang dan jasa memberikan kepemilikan suatu komoditas kepada pembeli untuk

suatu harga tertentu. Penjualan dapat dilakukan melalui berbagai metode, seperti penjualan langsung, dan melalui agen penjualan. Sedangkan menurut Daryono (2011:187), bahwa volume penjualan merupakan ukuran yang menunjukkan banyaknya atau besarnya jumlah barang atau jasa yang terjual. Volume penjualan sangat berpengaruh terhadap besar kecilnya laba yang akan diperoleh oleh perusahaan. Besarnya penjualan akan berpengaruh terhadap volume penjualan produk, begitu sebaliknya apabila penjualan tidak mencapai target optimal volume penjualan juga akan menurun. Hal ini membuktikan bahwa volume penjualan berpengaruh terhadap laba.

Penelitian yang berkaitan dengan penelitian yang dilakukan saat ini yaitu penelitian yang dilakukan oleh Kurniawan, Raryid, dan Kasyim (2012) dengan judul "pengaruh harga jual dan volume penjualan terhadap pendapatan pedagang pengumpul ayam potong". Hasil penelitian menunjukkan bahwa harga jual dan volume penjualan berpengaruh signifikan terhadap pendapatan pedagang pengumpul ayam potong di Kota makassar.
UD. Broiler Putra merupakan perusahaan yang bergerak dibidang ternak ayam broiler. Pembangunan bidang peternakan merupakan bagian dari pembangunan keseluruhan yang bertujuan untuk menyediakan pangan hewani berupa daging serta telur yang bernilai gizi tinggi. Pembangunan dalam bidang peternakan ini diharapkan dapat meningkatkan pendapatan dan dapat memperluas kesempatan kerja. Jumlah penduduk yang semakin meningkat dari tahun ke tahun terus diimbangi dengan kesadaran akan pentingnya nilai gizi bagi kesehatan dalam kehidupan sehati-hari. Hal ini dapat mempengaruhi peningkatan pola konsumsi makanan terutama protein hewani. Inilah yang mendorong pembangunan sektor peternakan sehingga di masa yang akan datang diharapkan dapat meningkatkan pembangunan perekonomian bangsa. Dalam usahanya, perusahaan ini tidak hanya menjual ayam yang masih hidup tetapi dalam juga menjual ayam potong dan telur. Dimana terdapat 2 buah bangunan ternak. 1 bangunan ternak digunakan sebagai tempat pemeliharaan ayam potong dan 1 bangunan ternak digunakan sebagai tempat pemeliharaan ayam petelur. Setiap bulannya usaha ini mendatangkan 2.000 atau 3.000 ekor itik yang akan dipelihara terlebih dahulu kemudian setelah satu bulan akan dijual hidup maupun sebagai ayam potong. Harga yang ditawarkan untuk 1 ekor ayam bervariasi, dari harga Rp. 45.000 sampai dengan Rp. 50.000 per ekor. Perusahaan ini juga bekerja sama dengan usaha-usaha kecil yang berada dalam satu kawasan.

Berdasarkan latar belakang masalah di atas maka peneliti tertarik untuk mengetahui yaitu pertama, pengaruh harga jual terhadap pendapatan. Kedua, pengaruh volume penjualan terhadap pendapatan. Ketiga, pengaruh harga jual dan volume penjualan terhadap pendapatan.

\section{METODE}

Rancangan dalam penelitian ini adalah kausalitas. Menurut Sugiyono (2012) "penelitian kausal adalah penelitian tentang hubungan yang bersifat sebab akibat". 
Penelitian yang bersifat sebab akibat yaitu terdapat variabel independen (mempengaruhi) dan variabel dependen (dipengaruhi). Dalam penelitian ini variabel bebas yaitu harga jual (X1) dan volume penjualan (X2) sedangkan variabel terikat yaitu pendapatan (Y). Penelitian ini bertujuan untuk mengetahui pengaruh harga jual dan volume penjualan terhadap pendapatan.

Dalam penelitian ini penelitii menggunakan jenis data kuantitatif. Data yang dimaksud dalam penelitian ini yaitu harga jual, volume penjualan, dan pendapatan. Jenis data menurut sumbernya dalam penelitian ini menggunakan data sekunder. Data sekunder dalam penelitian ini adalah data berupa angka yang diperoleh dari dokumen terarsip oleh UD. Broiler Putra dari tahun 2015-2017.

Adapun metode pengumpulan data yang digunakan dalam penelitian ini yaitu dokumentasi. Dokumentasi adalah pengumpulan data dengan membaca atau mencatat laporan keuangan yang ada dalam pembukuan bulanan UD. Broiler Putra.

Teknik analisis data pada penelitian ini menggunakan analisis regresi linier berganda. Sedangkan untuk menguji hipotesis dalam penelitian ini yaitu menggunakan uji $t$, uji $F$. Di mana uji $t$ digunakan untuk menguji tingkat signifikasi pengaruh variabel bebas terhadap variabel terikat secara parsial. Sedangkan uji F digunakan untuk menguji tingkat pengaruh variabel bebas terhadap variabel terikat secara bersama-sama atau simultan. Pengujian hipotesis dalam penelitian ini menggunakan bantuan SPSS (Statistical Program Social Science) versi 16.0 for windows. Regresi linear berganda digunakan untuk mengetahui pengaruh lebih dari satu variabel bebas pada variabel terikat. Regresi linear berganda digunakan apabila jumlah variabel bebas lebih dari satu. Analisis regresi linier berganda merupakan analisis yang menguji dua variabel bebas atau lebih terhadap satu variabel terikat, dengan menggunakan rumus regresi sebagai berikut.

$\hat{Y}=a+b_{1} X_{1}+b_{2} X_{2}+e$

Ghozali (2009:13).
Keterangan:

$\hat{Y} \quad=$ Variabel terikat (Pendapatan)

$\mathrm{X}_{1}=$ Variabel bebas 1 (harga jual)

$\mathrm{X}_{2}=$ Variable bebas 2 (volume penjualan)

a $=$ Konstanta

$\mathrm{b}_{1}=$ Koefisien regresi $\mathrm{X}_{1}$

$b_{2}=$ Koefisien regresi $X_{2}$

$\mathrm{e}=$ error (pengaruh variabel lain yang tidak ada dalam penelitian)

Uji $t$ digunakan untuk menguji signifikansi pengaruh variabel $X$ terhadap $Y$, apakah variabel harga jual (X1) benarbenar berpengaruh terhadap variabel $Y$ (pendapatan) dan volume penjualan (X2) terhadap penjualan ( $\mathrm{Y}$ ) secara terpisah atau parsial. Pengujian dilakukan dengan menggunakan significance level 0,05 $(\alpha=5 \%)$. Penerimaan atau penolakan hipotesis dilakukan dengan kriteria yaitu pertama, jika nilai signifikansi > 0,05 maka $\mathrm{HO}$ ditolak (koefisien regresi tidak signifikan). Ini berarti bahwa secara parsial variabel bebas tersebut tidak mempunyai pengaruh signifikan terhadap variabel terikat. Kedua, jika signifikan < 0,05 maka $\mathrm{HO}$ diterima (koefisien regresi signifikan). Ini berarti secara parsial variabel bebas tersebut mempunyai pengaruh yang signifikan terhadap variabel terikat. Sedangkan uji $\mathrm{F}$ digunakan untuk menguji tingkat pengaruh lebih dari satu variabel bebas terhadap variabel terikat secara bersama-sama atau simultan. Dalam penelitian ini juga menggunakan uji asumsi klasik, karena analisis yang digunakan dalam penelitian ini adalah analisis regresi linier berganda. Untuk menguji layak atau tidaknya analisis regresi digunakan terlebih dahulu dilakukan uji asumsi klasik. Adapun uji asumsi klasik yang digunakan terdiri dari uji normalitas, uji heterokedastisitas, uji multikolinearitas, dan uji autokorelasi.

$$
\text { Koefisien determinasi }
$$

dimaksudkan untuk mengetahui tingkat ketepatan paling baik dalam analisis regresi dimana hal yang ditujukan oleh besarnya koefisien determinasi (R2) antara 0 sampai dengan 1. Koefisien determinasi (R2) nol variabel independen sama sekali tidak berpengaruh terhadap variabel dependen. Apabila koefisien determinasi semakin mendekati satu, maka dapat dikatakan bahwa variabel independen berpengaruh 
terhadap variabel dependen, selain itu koefisien determinasi (R2) dipergunakan untuk mengetahui presentase perubahan variabel terikat $(Y)$ yang disebabkan oleh variabel bebas $(\mathrm{X})$.

Ada tiga rumusan hipotesis dalam penelitian ini yaitu harga jual berpengaruh positif dan signifikan terhadap pendapatan, volume penjualan berpengaruh positif dan signifikan terhadap pendapatan, harga jual dan volume penjualan berpengaruh positif dan signifikan secara simultan terhadap pendapatan.

\section{HASIL DAN PEMBAHASAN}

\section{Hasil Penelitian}

Berdasarkan hasil penelitian yang dilakukan oleh peneliti maka didapatkan

hasil dari pengujian yang dilakukan dengan bantuan SPSS versi 16 for windows. Pengaruh parsial harga jual terhadap pendapatan UD. Broiler Putra pada tahun 2015-2017 dianalisis dengan menggunakan uji statistik $t_{\text {test }}$ dengan program SPSS versi 16 for windows. Hasil analisis tersebut menunjukkan pengaruh harga jual terhadap pendapatan UD. Broiler Putra secara parsial dapat dilihat pada Tabel 1.

Tabel 1. Hasil Uji t untuk Variabel Harga Jual

Coefficients $^{a}$

\begin{tabular}{|c|c|c|c|c|c|c|}
\hline \multirow[b]{2}{*}{ Model } & & \multicolumn{2}{|c|}{$\begin{array}{c}\text { Unstandardized } \\
\text { Coefficients }\end{array}$} & \multirow{2}{*}{$\begin{array}{c}\begin{array}{c}\text { Standardized } \\
\text { Coefficients }\end{array} \\
\text { Beta }\end{array}$} & \multirow[b]{2}{*}{$\mathrm{T}$} & \multirow[b]{2}{*}{ Sig. } \\
\hline & & $B$ & Std. Error & & & \\
\hline 1 & (Constant) & -20932.765 & 3287.711 & & -6.367 & .000 \\
\hline & Harga jual & 482.256 & 79.012 & .208 & 6.104 & .000 \\
\hline
\end{tabular}

a. Dependent Variable: Pendapatan

Berdasarkan

Tabel

memperlihatkan bahwa variabel harga jual secara parsial berpengaruh terhadap pendapatan UD. Broiler Putra, karena dari uji yang dilakukan diperoleh hasil thitung sebesar $6,104>\mathrm{t}$ tabel sebesar 1,692 dengan taraf signifikansi $0,000<\alpha=0,05$ maka $\mathrm{H}_{\text {nol }}$ ditolak. Dengan demikian, dapat disimpulkan bahwa variabel harga jual secara parsial memiliki pengaruh positif yang signifikan terhadap pendapatan
UD. Broiler Putra pada tahun 2015-2017. Pengaruh parsial volume penjualan terhadap pendapatan UD. Broiler Putra pada tahun 2015-2017 dianalisis dengan menggunakan uji statistik $t_{\text {test }}$ dengan program SPSS versi 16 for windows. Hasil analisis tersebut menunjukkan pengaruh volume penjualan terhadap pendapatan UD. Broiler Putra secara parsial dapat dilihat pada Tabel 2.

Tabel 2. Hasil Uji t untuk Variabel Volume Penjualan

Coefficients $^{\mathrm{a}}$

\begin{tabular}{|c|c|c|c|c|c|c|}
\hline \multirow{2}{*}{\multicolumn{2}{|c|}{ Model }} & \multicolumn{2}{|c|}{$\begin{array}{l}\text { Unstandardized } \\
\text { Coefficients }\end{array}$} & \multirow{2}{*}{$\begin{array}{c}\begin{array}{c}\text { Standardized } \\
\text { Coefficients }\end{array} \\
\text { Beta }\end{array}$} & \multirow[b]{2}{*}{$\mathrm{T}$} & \multirow[b]{2}{*}{ Sig. } \\
\hline & & $B$ & Std. Error & & & \\
\hline \multirow[t]{2}{*}{1} & (Constant) & -20932.765 & 3287.711 & & -6.367 & .000 \\
\hline & $\begin{array}{l}\text { Volume } \\
\text { penjualan }\end{array}$ & 43.019 & 1.744 & .838 & 24.662 & .000 \\
\hline
\end{tabular}

a. Dependent Variable:

Pendapatan

Berdasarkan Tabel 2

memperlihatkan bahwa variabel volume

penjualan secara parsial berpengaruh terhadap pendapatan UD. Broiler Putra, 
karena karena dari uji yang dilakukan diperoleh hasil thitung sebesar 24,662 > t tabel sebesar 1,692 dengan taraf signifikansi $0,000<\alpha=0,05$ maka $\mathrm{H}_{\text {nol }}$ ditolak. Dengan demikian, dapat disimpulkan bahwa variabel harga jual secara parsial memiliki pengaruh yang positif signifikan terhadap pendapatan UD. Broiler Putra pada tahun 2015-2017.

Pengaruh simultan dari variabel harga jual dan volume penjualan terhadap pendapatan UD. Broiler Putra pada Tahun
2015-2017 dilakukan dengan menggunakan uji $F$ dengan program SPSS versi 16 for windows. Uji $\mathrm{F}$ ini menunjukkan analisis regresi linier berganda yaitu harga jual dan volume penjualan memiliki pengaruh yang simultan terhadap pendapatan UD. Broiler Putra. Hasil analisis yang menunjukkan bahwa pengaruh harga jual dan volume penjualan terhadap pendapatan UD. Broiler Putra berpengaruh secara simultan dapat dilihat pada Tabel 3.

\begin{tabular}{|c|c|c|c|c|c|c|}
\hline \multicolumn{7}{|c|}{$\begin{array}{c}\text { Tabel 3. Hasil Uji F } \\
\text { ANOVA }^{\mathbf{b}}\end{array}$} \\
\hline Model & & $\begin{array}{l}\text { Sum of } \\
\text { Squares }\end{array}$ & Df & Mean Square & $F$ & Sig. \\
\hline \multirow[t]{3}{*}{1} & Regression & 8.922E8 & 2 & 4.461E8 & 766.870 & $.000^{\mathrm{a}}$ \\
\hline & Residual & 1.920E7 & 33 & 581723.482 & & \\
\hline & Total & $9.114 \mathrm{E} 8$ & 35 & & & \\
\hline a. Pre & tors: (Con & , Volume $p$ & $\overline{l a n, 1}$ & Harga jual & & \\
\hline
\end{tabular}

b. Dependent Variable: Pendapatan

Berdasarkan hasil analisis pada Tabel 3 menunjukkan bahwa diperoleh nilai $F_{\text {hitung sebesar } 766,870>t \text { tabel }}$ sebesar 3,28 dengan taraf signifikan 0,000 $<\alpha=0,05$. Hal ini menunjukkan bahwa $\mathrm{H}_{\text {nol }}$ ditolak, jadi dapat disimpulkan bahwa variabel harga jual dan volume penjualan memiliki pengaruh yang signifikan secara

simultan terdadap pendapatan UD. Broiler Putra.

Untuk mengetahui besarnya pengaruh harga jual dan volume penjualan terhadap pendapatan UD. Broiler Putra, maka dapat digunakan analisis koefisien determinasi (Adjusted $R$ Square). Besarnya koefisien determinasi (Adjusted $R$ Square) dapat dilihat pada Tabel 4 .

Tabel 4. Hasil Perhitungan Koefisien Determinasi (Adjusted $R$ Square) dalam Model Summary

\section{Model Summary}

\begin{tabular}{|c|c|c|c|c|}
\hline Model & $\mathrm{R}$ & R Square & $\begin{array}{l}\text { Adjusted R } \\
\text { Square }\end{array}$ & $\begin{array}{l}\text { Std. Error of } \\
\text { the Estimate }\end{array}$ \\
\hline 1 & $.989^{a}$ & .979 & .978 & 762.708 \\
\hline
\end{tabular}

Berdasarkan hasil analisis pada Tabel 4 dengan menggunakan program SPSS versi 16 for windows menunjukkan bahwa besarnya pengaruh variabel harga jual dan volume penjualan terhadap variabel pendapatan secara simultan sebesar 0,978 sehingga besarnya pengaruh harga jual dan volume penjualan terhadap pendapatan secara simultan adalah sebesar $97,8 \%$. Hal ini berarti bahwa pendapatan UD. Broiler Putra pada Tahun 2015-2017 sebesar 97,8\% dipengaruhi oleh harga jual dan volume penjualan, sedangkan sisanya 2,2\% dipengaruhi oleh variabel lain yang tidak diteliti dalam penelitian ini. 
Berdasarkan pengolahan data yang digunakan untuk mengetahui persamaan garis regresi, pengaruh harga jual dan volume penjualan terhadap
Tabel 5. Hasil Perhitungan Koefisien Beta

pendapatan UD. Broiler Putra pada tahun 2015-2017 digunakan analisis koefisien beta. Besarnya koefisien beta dapat dilihat pada Tabel

\begin{tabular}{|c|c|c|c|c|c|c|}
\hline \multirow[b]{2}{*}{ Mode } & & \multicolumn{2}{|c|}{$\begin{array}{l}\text { Unstandardized } \\
\text { Coefficients }\end{array}$} & \multirow[t]{2}{*}{$\begin{array}{l}\text { Standardized } \\
\text { Coefficients }\end{array}$} & \multirow[b]{2}{*}{$\mathrm{T}$} & \multirow[b]{2}{*}{ Sig. } \\
\hline & & $B$ & Std. Error & & & \\
\hline \multirow[t]{3}{*}{1} & (Constant) & -20932.765 & 3287.711 & & -6.367 & .000 \\
\hline & Harga jual & 482.256 & 79.012 & .208 & 6.104 & .000 \\
\hline & $\begin{array}{l}\text { Volume } \\
\text { penjualan }\end{array}$ & 43.019 & 1.744 & .838 & 24.662 & .000 \\
\hline
\end{tabular}

a. Dependent Variable: Pendapatan

Berdasarkan hasil analisis pada Tabel 5 dengan menggunakan program SPSS versi 16 for windows dapat dibuat persamaan garis regresi. Persamaan garis regresi dapat dibuat untuk menggambarkan pengaruh harga jual dan volume penjualan terhadap pendapatan UD. Broiler Putra adalah sebagai berikut. $\hat{Y}=-209.32,765+482,256 X 1+43,019 X 2$ Keterangan:

$\hat{Y} \quad=$ pendapatan

$\mathrm{X} 1=$ harga jual

$\mathrm{X} 2$ = volume penjualan

Persamaan garis regresi tersebut mengartikan bahwa pada saat nilai X1 (harga jual), $\mathrm{X} 2$ (volume penjualan), bernilai 0 atau konstan, maka $Y$ (pendapatan) sebesar -209.32,765. Setiap ada kenaikan variabel bebas baik X1 (harga jual) maupun X2 (volume penjualan) sebesar satu satuan maka akan meningkatkan $Y$ (pendapatan) sebesar nilai koefisien nilai beta masingmasing variabel bebas dikalikan dengan besarnya kenaikan yang terjadi. Nilai 482,256 mengartikan bahwa setiap terjadi 1 peningkatan harga jual (X1), maka terjadi peningkatan harga jual (X1) sebesar 482,256 terhadap pendapatan (Y). Nilai 43,019 mengartikan bahwa setiap terjadi 1 peningkatan volume penjualan (X2), maka terjadi peningkatan volume penjualan (X2) sebesar 43,019 terhadap pendapatan $(\mathrm{Y})$.

\section{Pembahasan}

Berdasarkan hasil penelitian yang diperoleh mengenai pengaruh haega jual dan volume penjualan terhadap pendapatan, maka Hasil analisis data pada penelitian ini menunjukkan bahwa harga jual memiliki pengaruh parsial yang signifikan terhadap pendapatan UD. Brooiler Putra pada Tahun 2015-2017. Temuan ini sejalan dengan pernyataan Tjiptono (2005:151), bahwa harga jual merupakan satuan moneter atau satuan lainnya (termasuk barang dan jasa lainnya) yang ditukar agar memperoleh hak kepemilikan atau penggunaan suatu barang atau jasa yang akan berpengaruh terhadap pendapatan perusahaan.

Harga jual secara teoritik berpengaruh terhadap pendapatan UD. Broiler Putra. Hal ini dikarenakan pendapatan UD. Broiler Putra didapatkan dari jumlah harga jual dikalikan dengan volume penjualan. Semakin besar harga jual yang ditentukan semakin besar pula pendapatan yang dihasilkan oleh UD. Broiler Putra tersebut, begitu juga sebaliknya jika semakin kecil harga jual yang ditentukan maka pendapatan juga akan menurun. Asumsi teori ekonomi klasik menyatakan bahwa setiap perusahaan selalu memilih harga jual paling tinggi (Tjiptono, 2005:152). Harga jual sangat berhubungan dengan pendapatan, karena harga jual yang ditetapkan perusahaan terhadap produk 
yang dijual akan memberikan pendapatan atau keuntungan kepada perusahaan, maka harga jual mempunyai peran yang penting didalam perusahaan dan menentukan tinggi atau rendahnya pendapatan suatu perusahaan (Rivandi dan Jannah, 2018). Penelitian ini sejalan dengan penelitian yang dilakukan oleh Crisdandi (2015) hasil dari penelitian ini yaitu adanya pengaruh positif yang signifikan harga jual terhadap pendapatan.

Hasil analisis data pada penelitian ini menunjukkan bahwa volume penjualan memiliki pengaruh parsial yang signifikan terhadap pendapatan UD. Broiler Putra pada tahun 2015-2017. Temuan ini sejalan dengan Daryono (2011: 187), bahwa volume penjualan merupakan ukuran yang menunjukkan banyaknya atau besarnya jumlah barang atau jasa yang terjual. Volume penjualan merupakan salah satu hal penting yang harus dievaluasi untuk kemungkinan perusahaan agar tidak mengalami kerugian. Semakin besar volume penjualan suatu produk, maka semakin besar pula pendapatan yang diperoleh pedagang pengumpul (Astuti, 2005). Besarnya penjualan akan berpengaruh terhadap volume penjualan produk, begitu sebaliknya apabila penjualan tidak mencapai target optimal volume penjualan juga akan menurun. Hal ini membuktikan bahwa volume penjualan berpengaruh terhadap pendapatan. Penelitian ini sejalan dengan penelitian yang dilakukan oleh Sumantri (2017) hasil dari penelitian ini yaitu adanya pengaruh signifikan volume penjualan terhadap pendapatan. Hasil analisis data dalam penelitian ini menunjukkan bahwa harga jual dan volume penjualan berpengaruh secara simultan terhadap pendapatan UD. Broiler Putra. Oleh karena itu, penentuan harga jual sangat menentukan jumlah pendapatan yang diterima oleh UD. Broiler Putra. Selain itu, pendapatan juga dipengaruhi oleh volume penjualan. Apabila volume penjualan meningkat maka pendapatan juga akan meningkat, begitu juga sebaliknya apabila volume penjualan menurut maka pendapatan juga akan menurun atau berkurang.
Hasil penelitian ini sejalan dengan hasil penelitian yang dilakukan oleh Kurniawan, Kasyim, dan Raryid, (2012). Hasil penelitian ini membuktikan bahwa adanya pengaruh harga jual dan volume penjualan terhadap pendapatan.

\section{SIMPULAN DAN SARAN}

Berdasarkan hasil penelitian dan pembahasan maka dapat ditarik simpulan dalam penelitian ini. Pertama, Ada pengaruh positif dan signifikan secara parsial harga jual terhadap pendapatan UD. Broiler Putra, yang ditunjukkan dengan koefisiaen regresi sebesar 6,104. Dan nilai signifikan uji t sebesar 0,000 yang berarti lebih kecil dari 0,05 atau $\alpha=$ $5 \%$. Hal ini berarti, semakin besar harga jual yang ditetapkan maka pendapatan UD. Broiler Putra juga semakin meningkat. Kedua, Ada pengaruh positif dan signifikan secara parsial volume penjualan terhadap pendapatan UD. Broiler Putra, yang ditunjukkan dengan koefisiaen regresi sebesar 24,035. Dan nilai signifikan uji t sebesar 0,000 yang berarti lebih kecil dari 0,05 atau $\alpha=5 \%$. Hal ini berarti, semakin tinggi tingkat volume penjualan maka pendapatan UD. Broiler Putra juga semakin meningkat. Ketiga, Ada pengaruh positif dan signifikan secara simultan harga jual dan volume penjualan terhadap pendapatan UD. Broiler Putra, yang ditunjukkan dengan koefisiaen regresi sebesar 766,870. Dan nilai signifikan uji $\mathrm{F}$ sebesar 0,000 yang berarti lebih kecil dari 0,05 atau $\alpha=5 \%$. Hal ini berarti, penetapan harga jual dan memperhatikan volume penjualan akan mempengaruhi besar kecilnya pendapatan yang diperoleh oleh UD. Broiler Putra.

Berdasarkan hasil penelitian, pembahasan dan simpulan, maka dapat diajukan saran dalam penelitian ini. Pertama, Bagi UD. Broiler Putra, sebaiknya UD. Broiler Putra lebih memperhatikan penetapan harga jual, karena penetapan harga jual sangatlah penting dalam upaya meningkatkan pendapatan. Semakin tinggi tingkat harga jual maka semakin tinggi pula pendapatan yang akan diterima oleh UD. Broiler Putra tersebut. Kedua, Bagi UD. Broiler Putra, 
selaain memperhatikan harga jual, UD. Broiler Putra juga harus memperhatikan tingkat volume penjualan. Karena volume penjualan juga sangat mempengaruhi pendapatan yang akan diterima oleh UD. Broiler Putra. Semakin besar tingkat volume penjualan, maka pendapatan yang diterima oleh UD. Broiler Putra juga akan semakin besar. Ketiga, bagi peneliti selanjutnya yang tertarik untuk mengkaji aspek yang serupa mengenai pengaruh harga jual dan volume penjualan terhadap pendapatan diharapkan untuk mengembangkan penelitian ini dengan menggunakan variabel lain yang mempengaruhi pendapatan, namun tidak masuk dalam model yang diuji dalam penelitian ini. Sehingga pendapatan tidak hanya dipengaruhi oleh harga jual dan volume penjualan namun juga dapat dipengaruhi oleh variabel lain.

\section{DAFTAR PUSTAKA}

Adji, Wahyu. 2004. Ekonomi Kelas XI Kurikulum Berbasis Kompetensi. Jakarta: Erlangga.

Astuti. 2005. "Pengaruh Nilai Margin Pemasaran Terhadap Pengrajin Gula Kelapa Di Desa Karang Duren, Kecamatan Tanggerang, Kabupaten Semarang." Universitas Negeri Semarang.

Crisdandi, Putu. 2015. "Pengaruh Biaya Pemeliharaan Dan Harga Jual Terhadap Pendapatan Petani Cengkeh Di Desa Tirtasari Pada Tahun 2014." Universitas Pendidikan Ganesha 5 (1),1-11.

Daryono. 2011. Manajemen Pemasaran. Bandung: CV. Yrama Widya.

Dyekman. 2002. Pengantar Bisnis Intruduction to Business 4th Ed. Jakarta: Salemba Empat.

Ghozali, Imam. 2009. Ekonometrika Teori Konsep Dan Aplikasi Dengan SPSS 17. Semarang: Universitas Diponegoo.

Hery. 2009. Teori Akuntansi. Jakarta: Kencana Prenada Media Group.

Jakfar dan Kasmir. 2012. Studi Kelayakan
Bisnis. jakarta: kencana.

Kurniawan, Kasyim \& Raryid,. 2012. "Pengaruh Harga Jual Dan Volume Penjualan Terhadap Pendapatan Pedagang Pengumpul Ayam Potong." Universitas Hasanuddin 1, 1-8.

Kotler, Philip. 2005. Manajemen Pemasaran Analisis Perencanaan Implementasi Dan Kontrol, Edisi Bahasa Indonesia. Jakarta: prehallindo.

Mulyadi. 2008. System Akuntansi. Jakarta: Salemba Empat.

Rangkuti, Freddy. 2001. Creating Effective Marketing Plan. Gramedia Pustaka Utama.

Rivandi dan Janah. 2018. "Pengaruh Biaya Pemeliharaan Dan Harga Jual Terhadap Pendapatan (Studi Kasus Pada PT. Perindustrian Dan Perdagangan Lembah Karet)." Jurnal Sekolah Tinggi IImu Ekonomi KBP 110.

Sugiyono. 2012. Metode Penelitian Pendekatan Kuantitatif, Kualitatif, Dan R\&D. Bandung: Alfabeta.

Sumantri. 2017. "Pengaruh Volume Penjualan Terhadap Pendapatan Ayam Potong (Studi Kasus Peternakan Ayam Supadi)." volume 2.

Sunyoto, Danang. 2012. Dasar-Dasar Manajemen Pemasaran. Yogyakarta: Caps.

Supriyono. 2009. Akuntansi Biaya. yogyakarta: Badan Penerbit Fakultas Ekonomi.

Swastha, Basu. 2007. Azas-Azas Marketing. Yogyakarta: Liberty.

Tjiptono, Fandy. 2005. Strategi Pemasaran. Yogyakarta: ANDI.

Zulkarnain. 2012. IImu Menjual. Pekan Baru: Graha Ilmu. 